\title{
UTILIZATION OF CEMENT KILN DUST IN DOMESTIC SEWAGE SLUDGE TREATMENT FOR SAFE DISPOSAL AND ENVIRONMENTAL PROTECTION
}

\author{
El-Awady, M. H. ${ }^{(1)}$; Abo-El-Enein, S. A. ${ }^{(2)}$ and Anwar, Sh. M. ${ }^{(3)}$ \\ 1) Environmental Science Division, National Council Center, 2) Faculty of \\ Science, Ain Shams University 3) Holding Company for Water and \\ Wastewater
}

\begin{abstract}
Recent years, wastewater treatment plants are producing huge amounts of primary and secondary sewage sludge. On the other hand, large quantities of cement kiln dust (CKD) were produced from cement factories with negative impacts on the environment. CKD is a considerable by-product waste material of the industrial process. At the time being, remarkable advances have been achieved in the management and reuse of CKD. Due to its high alkalinity, huge amounts, negative impact and abundant source; it is considered as noncontrolled source of pollution. Reuse of CKD in presence of waste sludge has high potential as an additional low cost raw material, fertilizer, constructing material, adsorbent and improving sandy soil properties. In this study, CKD was used as chemical coagulant / flocculent sewage sludge and adsorbent for soluble pollutants as well as microbial disinfectants. The optimum operating conditions were adjusted using Jar test experiment and tested sludge was analyzed. Results showed that on addition $8.0 \mathrm{~g} / \mathrm{l}$ CKD to primary sludge and 7.0 $\mathrm{g} / \mathrm{l}$ to return activated sludge (RAS) achieved good efficiency for solids separation, BOD5, COD, PO4, and NH4; respectively. Under the effect of high $\mathrm{pH}$ value, it was also beneficial in heavy metals immobilization and minimization of metal solubility in the treated sludge matrix. Consequently, metal ions were precipitated as hydroxides. Moreover, all pathogenic and viral species were destructed including total and fecal coliforms.
\end{abstract}


Keywords: Sewage sludge - Cement Kiln dust - Reuse - Adsorption $\mathrm{pH}$.

\section{INTRODUCTION}

The constituents removed in wastewater treatment plants include screenings, grit, scum, solids, and bio-solids. Solids were formed as a result of wastewater treatment plant activities. They are usually in the form of liquid or paste phases. Bio-solid is typically contains from 0.25 to $12 \%$ solids by weight depending on the used treatment process. The term bio-solids, as defined by the Water Environment Federation (WEF), reflected the fact that solids content are organic in nature that can be used beneficially after treatment using stabilization and composting. The term "Sludge" is generally used in conjunction with a process descriptor, such as primary sludge and waste-activated sludge (George et al., 2003). According to Yurtsever, 2005; the quantity and characteristics of sludge generated in a wastewater treatment plant was dependent on the physic-chemical composition of the wastewater, the type of wastewater treatment used, and the type of subsequent treatment applied to the sludge. The characteristics of the sludge produced can be changed annually, seasonally, or even daily because of continuous variations in the incoming wastewater composition as well as in treatment processes. The composition of the wastewater reflected on all the substances that were used in the community, due to wide variations in the wastewater contents. Cleverson et al., 2007 showed that the evaluation of alternatives for sewage sludge treatment and final disposal was usually complex, due to the interaction of technical, economic, environmental and legal aspects. Although 
complex and expensive, final sludge disposal was often neglected in the conception and design of wastewater systems, operators sometimes need to handle the final disposal of the sludge on an emergency basis, with all the burden of high costs, operational difficulties and undesirable environmental impacts that might undermine the benefits of the wastewater treatment system. Along Egypt about $3938 \mathrm{~m}^{3} / \mathrm{d}$ of primary sludge were discharging from three primary wastewater treatment plants with solid content of $4 \%$, and near $619253 \mathrm{~m}^{3} / \mathrm{d}$ of secondary sludge were produced from 270 secondary wastewater treatment plants with total solid percentage of $2 \%$, (Holding Company for Water and Wastewater-Technical Report, 2013). On the other hand, El-Mahllawy, 2013 reported that in Egypt, every year a huge amount of CKD was produced from cement industry during the manufacture of cement clinker via the dry process. The annual production of cement reached 30 million tons, with at least 3 million tons of CKD. It is generally grayish in color and consists predominately of silt-sized, non-plastic particles representing a mixture of partially calcite and un-reacted raw feed. Clinker dust and fuel ash enriched with alkali sulfates, halides and other volatiles. The environmental problems arise when CKD transported to be dumped as land filling that cause remarkable pollution to all surrounding environment. Reuse options were limited and the bulk of CKD was not reused in the cement manufacturing process but sent to landfills or stored on-site (Mackie et al., 2010). X-ray diffraction analysis of cement kiln dust showed that the main constituent is calcite $\left(\mathrm{CaCO}_{3}\right)$, quartz $\left(\mathrm{SiO}_{2}\right)$ and calcium sulfate $\left(\mathrm{CaSO}_{4}\right)$. CKD has potential as an amendment for the neutralization of acidity with high adsorption capability for aqueous metals and nutrients removal 
efficiencies (El-Awady, 1998b; Salem et al., 2015). Adsorption is the most effective and widely used technique for the removal of toxic heavy metals from wastewater as a reliable approach for sewage treatment in developing countries (El-Awady, 1998a; Selvi et al., 2001; El-Awady and Ali, 2012). Due to the high cost and difficult procurement of activated carbon as an adsorbent material, efforts were directed to find efficient and low-cost adsorbent materials (Mahmoud, 2010 and 2014). The high adsorption ability of cement kiln dust, and its availability in high quantities, as an inexpensive by-product of cement industry, it could be effective in the removal of all heavy metals with special efficiency for chromium from tannery wastewater (El-Awady and Sami, 1997; Al-Meshragi et al., 2008). The present study aims to study the role of cement kiln dust in the treatment of primary and return activated sludge as well as the possibility of reuse the treated sludge for agricultural purposes.

\section{MATERIALS AND METHODS}

\section{1- Materials:}

\subsection{Sewage sludge samples:}

Two types of sewage sludge were collected from; (i) Abu-Rawash wastewater treatment plant (ARWWTP). It is operating as primary treatment plant located in Giza, Egypt. Its production rate reached $5000 \mathrm{~m}^{3} /$ day liquid primary sludge with total solids percentage of $4 \%$, where around 90 liters of sample was collected. (ii) Zeinin wastewater treatment plant (ZWWTP) is operating as secondary treatment plant located in Giza, Egypt. It produces 
more than $20,000 \mathrm{~m}^{3}$ /day liquid RAS with solids percentage of $0.5 \%$, where about $75 \mathrm{~L}$ of sample was collected.

\subsection{Cement kiln dust (CKD):}

CKD was collected from Helwan Cement Company, located in Helwan District, Cairo, Egypt. It was dried for $24 \mathrm{~h}$ at $105^{\circ} \mathrm{C}$. The characterization of

\section{2- Methods:}

\subsection{Jar test procedures:}

The Jar test procedure was conducted using a standard apparatus (Velp scientific, Europe, c26- six paddle stirrer, with lamps to light during mix an alarm for timing) was used in all experiments. Paddles attached to shafts made from stainless steel. The stirrers feature variable speeds from 0 to 300 rpm, with digital read out panel. Jar test has been used to determine the optimum conditions (CKD dose; RPM; flocculation time and settling time) for CKD addition to primary and return activated sludge samples. After adjusting optimal operating conditions, complete analyses were carried out for raw and treated samples.

\subsection{Physico-chemical analyses of raw and treated samples}

The physical and chemical parameters have been carried out according to APHA (Standard Methods for the Examination of Water and Wastewater, $22^{\text {nd }}$ Edition, Eugene et al., 2012). Metals concentrations were measured using Inductively Coupled Plasma (ICP), Optical emission Spectrometer (7300DV, Perkin Elmer). pH's were measured using pH-Meter (Thermo scientific, USA). Total solid (TS) was the term applied to the material residue left in the vessel after evaporation of a sample and its subsequent drying in an oven at a defined temperature. Total suspended solids (TSS) is the portion of 
total solids retained by a filter, and Total dissolved solids (TDS) is the portion that passes through a filter of $2.0 \mathrm{~m}$ (or smaller) nominal pore size under specified conditions. Sludge volume index (SVI) is the volume in milliliters occupied by $1 \mathrm{~g}$ of a suspension after $30 \mathrm{~min}$ settling. Chemical Oxygen Demand (COD) was measured using Block heater of model Thermo Scientific, USA and colorimeter (Lamotte, USA). Biological oxygen demand $\left(\mathrm{BOD}_{5}\right)$ measured using incubator (WTW, Germany), DO meter (Thermo Scientific, USA) and bottles 300-mL (Wheaton, USA). Ammonia $\left(\mathrm{NH}_{3}\right)$ measured using Ion Selective electrode (thermo-orion star). Phosphate $\left(\mathrm{PO}_{4}^{-3}\right)$ digested on a hot plate using potassium persulphate and sulfuric acid then determined using double beam spectrophotometer (Lambda 25, Perkin Elmer, USA). Turbidity measured using colorimeter (lamotte, USA). Finally, sulphide $\left(\mathrm{S}^{-2}\right)$ was measured according to iodometric titration method.

\subsection{Determination of total and fecal Coliform:}

The total coliform (TC) and fecal Coliform (FC) were performed according to APHA, $22^{\text {nd }}$ Edition, 2012. The used media were M-Endo agar and M-FC agar. For detecting TC, the collected samples were serially diluted using sterile saline water 10 fold, $1 \mathrm{ml}$ of each dilution was seeded by membrane filter technique on the testing culture medium (M-Endo Medium).The inoculated plates were incubated for 24 hours at $35^{\circ} \mathrm{C}$. The typical coliform colonies on M-Endo medium were counted. For detecting FC, the collected samples were serially diluted using sterile saline water 10 fold; 1 $\mathrm{ml}$ of each dilution was seeded by membrane filter technique on the testing culture medium (M-FC Medium). The inoculated plates were incubated for 24 
hours at $44.5^{\circ} \mathrm{C}$, where the typical $\mathrm{FC}$ colonies on m-Endo medium were counted.

\section{RESULTS AND DISCUSSION}

1. Characterization of cement kiln dust:

Table (1): Chemical composition of CKD

\begin{tabular}{|c||c|c|c|}
\hline \hline Constituent & Weight (\%) & Constituent & Weight (\%) \\
\hline \hline $\mathrm{SiO}_{2}$ & 9.85 & $\mathrm{SO}_{3}^{--}$ & 7.45 \\
\hline $\mathrm{Al}_{2} \mathrm{O}_{3}$ & 2.27 & $\mathrm{Na}_{2} \mathrm{O}$ & 1.74 \\
\hline $\mathrm{Fe}_{2} \mathrm{O}_{3}$ & 1.98 & $\mathrm{~K}_{2} \mathrm{O}$ & 4.32 \\
\hline $\mathrm{CaO}$ & 33.02 & Insoluble Residue & --- \\
\hline $\mathrm{MgO}$ & 2.25 & Loss of Ignition & 10.85 \\
\hline
\end{tabular}

The chemical composition of CKD in Table (1) shows that it has multiple coagulants $\left(\mathrm{CaO}, \mathrm{MgO}, \mathrm{Al}_{2} \mathrm{O}_{3}\right.$ and $\mathrm{Fe}_{2} \mathrm{O}_{3}$; respectively), in addition to be an adsorbent at the same time due to presence of $\mathrm{SiO}_{2}(\mathrm{Rahman}$ et al., 2011).

\section{Evaluation of physical-chemical and microbiological quality of treated} sludge

\subsection{Jar test procedures}

The jar test procedures were conducted to detect the optimum conditions for CKD addition to primary and return activated sludge to obtain the best quality of the treated supernatant under investigation. Figure (1) shows the optimum dose of CKD for: (a) the primary sludge and (b) return activated sludge 
J. Environ. Sci.

Institute of Environmental Studies and Research - Ain Shams University

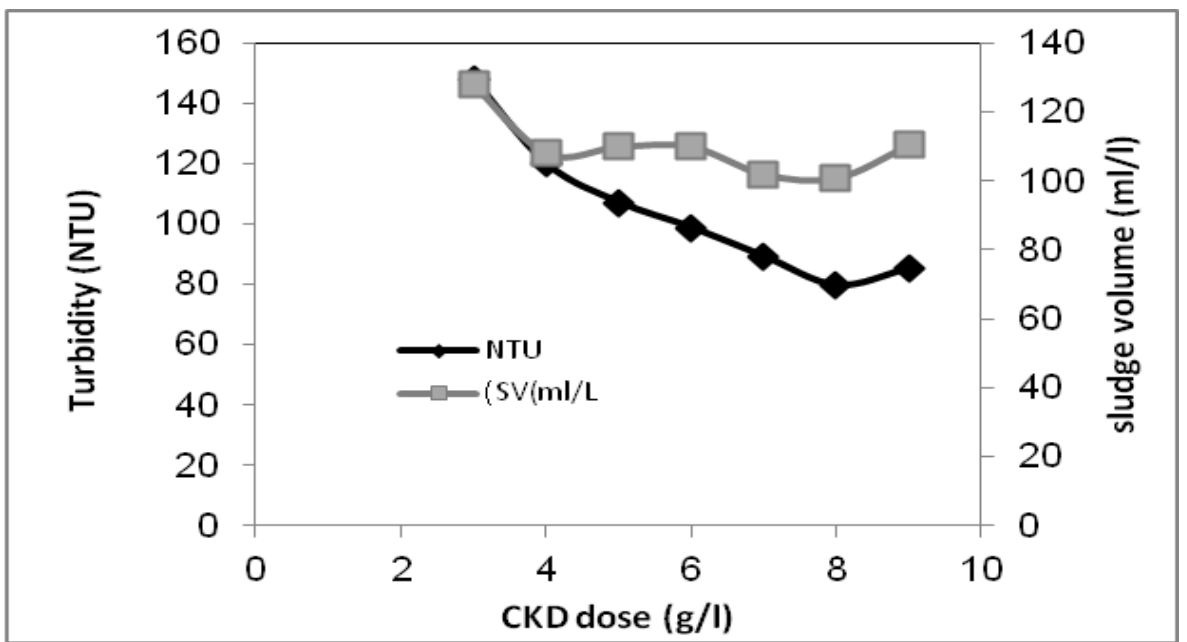

Figure (1): a.Optimum CKD dose for primary sludge treatment

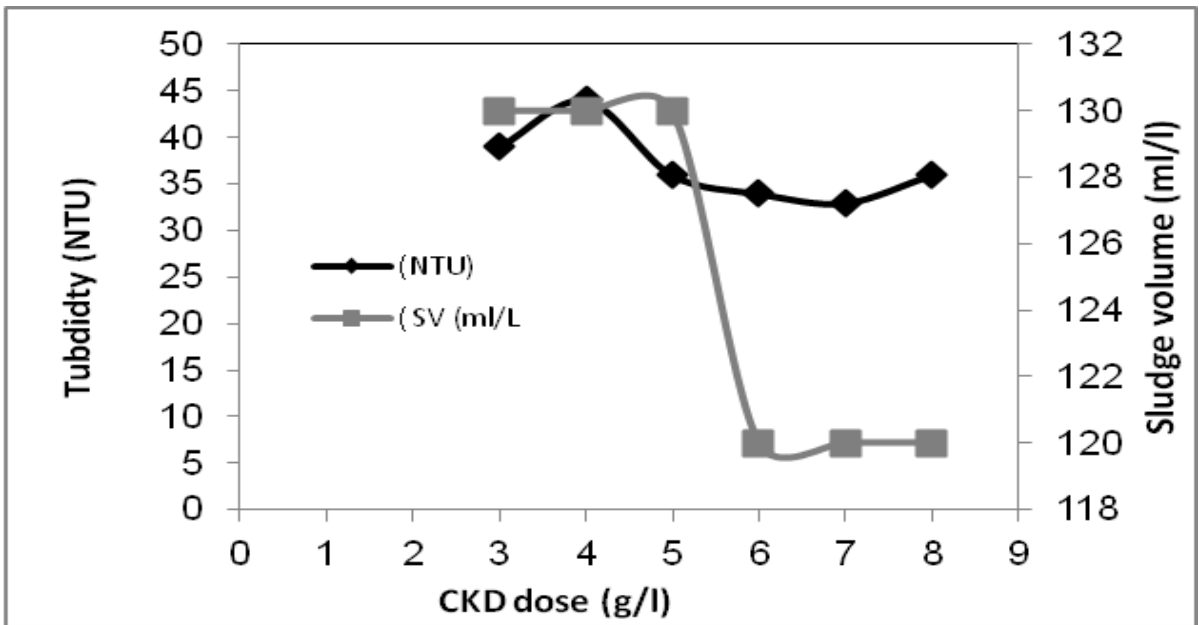

Figure (1): b. Optimum CKD dose for return activated sludge (RAS) treatment

Figures $(1 . \mathrm{a}-1 . \mathrm{b})$ show that the NTU decreases with increasing CKD dose, then increased again on extra addition. The optimum conditions for CKD addition to primary sludge found to be $8 \mathrm{~g} / \mathrm{L}$ at 1 min flash mixing, 2 8

Vol.33, No.2, June, 2016 
min flocculation, 15 min settling time, $15 \mathrm{RPM}$, at final $\mathrm{pH}$ value 12.6. On the other hand, the optimum conditions for CKD addition to RAS found to be: $7 \mathrm{~g} / \mathrm{L}$ at $2 \mathrm{~min}$ flash mixing, $10 \mathrm{~min}$ flocculation, $30 \mathrm{~min}$ settling time, 10 $\mathrm{RPM}$, at final $\mathrm{pH}$ value 12.1. Results showed an increase of $\mathrm{pH}$ up to 12.1 and 12.64 at the CKD optimal doses; whereas Usama and Rafik (2013) observed that when $1.2 \mathrm{~g} / \mathrm{l} \mathrm{CKD}$ added to raw samples, the $\mathrm{pH}$ increased to be 8.22. Moreover, El-Awady and Samy, 1997 found that the chemical analysis of CKD showed that sodium and potassium oxides have dominant effect on the increase of the $\mathrm{pH}$ of the aqueous CKD soaked solution.

\subsection{Physico-Chemical and Microbiological Analyses:}

They were carried out on raw primary and RAS samples, in addition to their treated supernatants. The optimum operating conditions have been determined. The jar test was used and the produced samples were analyzed to determine the effect of CKD addition to primary and RAS, respectively. Three Jar test runs were conducted for three different composite sludge samples. The averages of analyses were calculated to detect the removal efficiencies. Table (2) shows the physico-chemical analyses for primary sludge and its treated supernatants, respectively. 
Table (2): Physico-chemical analyses of primary sludge and treated supernatant

\begin{tabular}{|c|c|c|c|c|}
\hline Parameter & Unit & $\begin{array}{l}\text { primary } \\
\text { sludge* }\end{array}$ & $\begin{array}{l}\text { Treated samples with } \\
\text { CKD }\end{array}$ & $\mathbf{R} \%$ \\
\hline PH & - & 6.83 & 12.64 & - \\
\hline TSS & $\mathrm{mg} / \mathrm{l}$ & 5237 & 384.7 & 92 \\
\hline TS & $\mathrm{mg} / \mathrm{l}$ & 6572 & 4633.3 & 29.5 \\
\hline SV & $\mathrm{ml} / \mathrm{l}$ & 233 & 178.5 & 23.4 \\
\hline SVI & - & 38.1 & 29.1 & 23.6 \\
\hline COD & $\mathrm{mg} / \mathrm{l}$ & 10397 & 1209 & 88.4 \\
\hline $\mathrm{BOD}_{5}$ & $\mathrm{mg} / \mathrm{l}$ & 2063 & 362 & 82.4 \\
\hline $\mathrm{NH}_{3}$ & $\mathrm{mg} / \mathrm{l}$ & 28.8 & 3.6 & 87.6 \\
\hline $\mathrm{PO}_{4}^{-3}$ & $\mathrm{mg} / \mathrm{l}$ & 23.3 & 9.4 & 59.8 \\
\hline $\mathrm{S}^{-2}$ & $\mathrm{mg} / \mathrm{l}$ & 24.7 & 3.9 & 84.3 \\
\hline $\mathrm{Cu}$ & $\mathrm{mg} / \mathrm{l}$ & 0.42 & 0.1 & 77.2 \\
\hline $\mathrm{Fe}$ & $\mathrm{mg} / \mathrm{l}$ & 30 & 2 & 93.2 \\
\hline $\mathrm{Pb}$ & $\mathrm{mg} / \mathrm{l}$ & 0.13 & 0.02 & 88.4 \\
\hline Mn & $\mathrm{mg} / \mathrm{l}$ & 0.5 & 0.13 & 74.5 \\
\hline $\mathrm{Ni}$ & $\mathrm{mg} / \mathrm{l}$ & 0.1 & 0.01 & 80 \\
\hline $\mathrm{Zn}$ & $\mathrm{mg} / \mathrm{l}$ & 1.5 & 0.2 & 88.5 \\
\hline
\end{tabular}

*The average of three samples

The TSS removal was $92 \%$ which is comparable results to that stated by El-Awady and Samy, 1997, where the percent removal was characterized as $92.8 \%$. The high removal efficiency of TSS proved that CKD is relevant as a coagulant due to presence of $\mathrm{CaO}, \mathrm{MgO}, \mathrm{Al}_{2} \mathrm{O}_{3}$ and $\mathrm{Fe}_{2} \mathrm{O}$ in its composition, in addition to its good adsorbing capability (Rahman et al., 2011). The removal of TS was $29.5 \%$ and this is due to the high ability of increase the TDS concentration after addition of CKD dose. The decrease in Sludge volume (SV) by $23.3 \%$ and the decrease of Sludge volume Index (SVI) by $23.6 \%$ were 
matched with El-Awady, 1998b. On the other side, Allison et al., 2010 used $\mathrm{CKD}$ and quicklime slurries to treat mine wastewater who indicated that the lower sludge volumes could be generated through the use of CKD slurry if compared to traditional quicklime treatment. Organic load like COD and $\mathrm{BOD}_{5}$ were the basic and important parameters, so the removal of COD was up to $88.4 \%$ which is close to that concluded by El-Awady and Samy, 1997. They also declared that the use of CKD with $20 \mathrm{~g} / \mathrm{L}$ as an adsorbent has the capability to increase $\mathrm{pH}$-value from 3.64 to 8.2 ; with a removal efficiency of COD reached to $55.6 \%$, while the removal of TOC exceeded $88.8 \%$. The $\mathrm{BOD}_{5}$ removal was found to be $82.4 \%$ that matched with El-Awady (1998) where he reported that the effect of CKD as an efficient alternative coagulant in sewage treatment. He carried out a comparison in chemical coagulation between ferric chloride, lime and CKD and found that the removal efficiency of $\mathrm{BOD}_{5}$ using $\mathrm{CKD}$ was $77 \%$ from the initial value. The results obtained from this study showed that $\mathrm{NH}_{3}$ removal efficiency of $87.6 \%$, where EL-Awady (1998) found that ammonia removal was $66.5 \%$. Phosphate removal efficiency found to be 59.8\% which matched with El-Awady (1998). The sulphide content decreased with $84.3 \%$ which gave an indicator about the good quality treatment and this matching with Rahman, 2011 who found that CKD make good chemical elimination for hydrogen sulphide. Removal of metals like $\mathrm{Cu}$, $\mathrm{Fe}, \mathrm{Pb}, \mathrm{Mn}, \mathrm{Ni}$, and $\mathrm{Zn}$ were $77.16,93.23,88.39,74.50,80$, and $88.47 \%$, respectively. Results show that the final concentration of metals is within the limits. El-Awady and Samy (1997) reported the mechanism of heavy metals removal from acidic wastewater may be explained as follows: 
(1) Heavy metals hydrolysis:

$$
\mathrm{X}_{2} \mathrm{O}+\mathrm{H}_{2} \mathrm{O} \rightarrow 2 \mathrm{X}(\mathrm{OH}) ; \mathrm{X}(\mathrm{OH})+\mathrm{MSO}_{4} \rightarrow \mathrm{M}(\mathrm{OH})_{\mathrm{n}} \downarrow+\mathrm{XSO}_{4}
$$

Where X: K, Na, M: Cr, Fe, Cu, Co and n: 2, 3.

(2) Adsorption of heavy metals on the CKD fine particles :

$$
\mathrm{M}(\mathrm{OH})_{\mathbf{n}}+\mathrm{CKD} \rightarrow \mathrm{CKD}-\left(-\mathrm{M}(\mathrm{OH})_{\mathbf{n}}\right)
$$

It was reported that the removal of $\mathrm{Mn}, \mathrm{Cu}, \mathrm{Pb}, \mathrm{Cd}, \mathrm{Zn}$, and $\mathrm{Cr}$ were $100 \%$ at $20 \mathrm{~g} \mathrm{CKD} / \mathrm{L}$ and $150 \mathrm{rpm}$ for 30 minutes, while the removal of iron and nickel were $98 \%$ and $80 \%$, respectively. Physico-Chemical analyses for RAS and its treated supernatant samples are graphically represented in Figure (2).

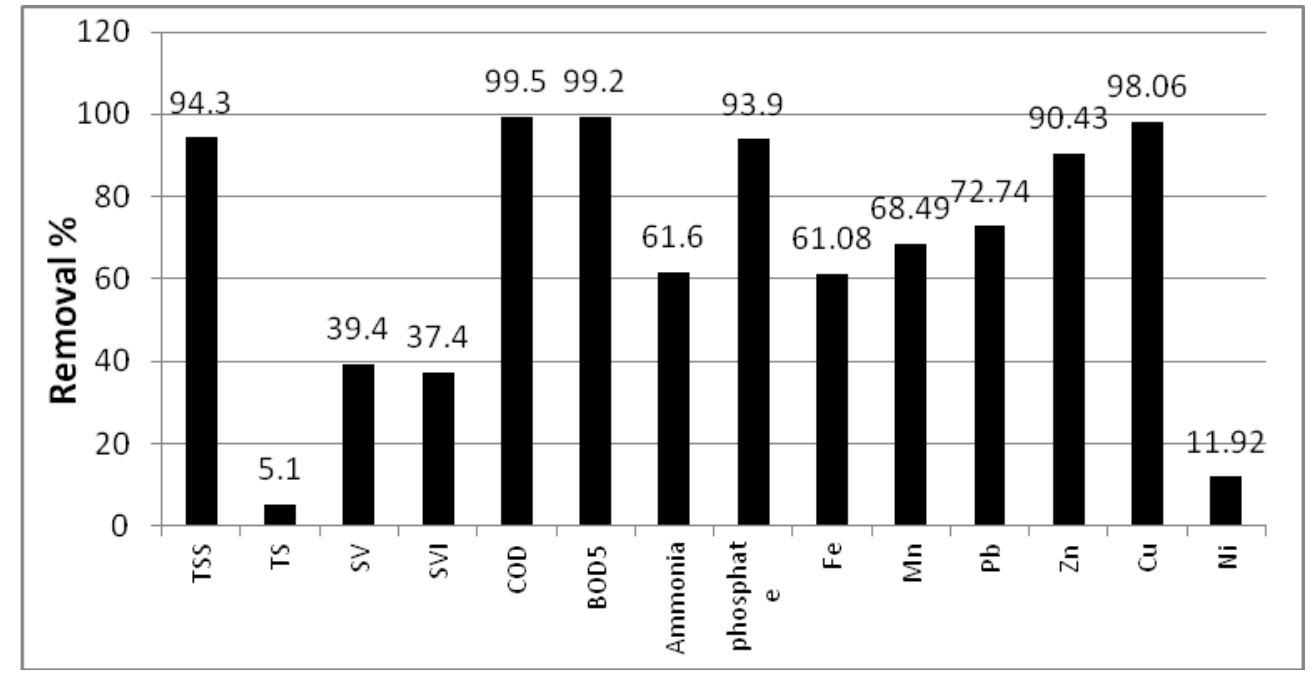

Figure (2): Efficiency of treatment

Figure (2) shows TSS removal efficiency up to $94.3 \%$ which refers to the characteristics of CKD as a good coagulant and flocculent. The R\% of SV and SVI was 39.4 and 37.4\%, respectively. Allison and Margaret, 2012, compared between $\mathrm{CKD}$ and quicklime slurries in the treatment of mine 12 
water and they found that sludge volumes were generated in CKD-treated samples were only 50-60\% of those generated with the quicklime slurry. The removal efficiencies of $\mathrm{BOD}_{5}, \mathrm{COD}$, and $\mathrm{PO}_{4}^{-3}$ were 99.2, 99.5 and $93.9 \%$ respectively. These results is matching with Mostafa (2012) who enhanced the removal efficiencies of $\mathrm{BOD}_{5}, \mathrm{COD}$, TSS, phosphate and pathogenic bacteria by adding CKD to wastewater as a chemical coagulant in a designed module at temperature ranges of $(30-35){ }^{\circ} \mathrm{C}$ and (15-20) ${ }^{\circ} \mathrm{C}$ to be complied with the Law 501/2005 for reuse limits for agricultural purposes. Mostafa (2012) stated that phosphate removal by chemical precipitation is the best known process and is widely used despite its relatively high costs. When $2 \mathrm{~g}$ $\mathrm{CKD} / \mathrm{L}$ was added for wastewater in his designed model, the average removal efficiencies for $\mathrm{BOD}_{5}, \mathrm{COD}$, TSS and phosphate were found to be $94.1 \%$, $94.1 \%, 94.2 \%$ and $87.9 \%$, respectively. Also, CKD addition decreased the bulking problems occurred at temperature range $(15-20){ }^{\circ} \mathrm{C}$, where SVI was decreased from 149 to 63 and as a result, bulking did not occur. The ammonia removal was $61.6 \%$. Mostafa, 2012 showed that CKD contain high ratio free of $\mathrm{CaO}$ which act as a good coagulant and flocculent also have cations as potassium and manganese which define cell membrane permeability and leads to high phosphate removal. Removals of heavy metals $(\mathrm{Cu}, \mathrm{Fe}, \mathrm{Pb}, \mathrm{Mn}$, $\mathrm{Ni}$, and $\mathrm{Zn}$ ) from treated RAS with CKD were consequently 77.1, 93.23, $88.39,74.5,80$ and $88.47 \%$. Taha et al. (2007) studied the adsorption of $\mathrm{Cd}$ (II), Al (III), Co (II) and Zn (II) using CKD and synthetic stock solution of heavy metals and found that the removal of zinc was about $80 \%$ at $\mathrm{pH} 6.5$ and it increased to $99 \%$ at $\mathrm{pH} 8$. For aluminum, $85 \%$ was removed at $\mathrm{pH} 5$ and it increased to $99 \%$ at $\mathrm{pH}$ 6. For cadmium, $90 \%$ was removed at $\mathrm{pH} 5.5$ and it 
increased to $99 \%$ at $\mathrm{pH} 6.2$.For Cobalt, removal increased proportionally with increasing $\mathrm{pH}$ from $50 \%$ at $\mathrm{pH} 6$ to $90 \%$ at $\mathrm{pH}$ 8. The obtained results of this work are in agreement with Salem et al., (2015) who found that mixing of sewage water with CKD (10 g/l) completely removed manganese, nickel, lead, zinc and iron (100\% removal) after 3 days of treatment. The removal of cadmium and cobalt were proportionally increased with increasing $\mathrm{pH}$ up to 8. Above $\mathrm{pH} 8$, the adsorption ability was decreased due to increasing in $\mathrm{OH}-$ ions.

Table (3) shows the microbiological analyses for the primary, return activated sludge and their treated supernatants, an average of three results and the efficiency of removal.

Table (3): Microbiological analyses of primary and treated sludge with CKD

\begin{tabular}{|c||c|c|c|c|c|c||}
\hline \multirow{2}{*}{ Parameter } & \multicolumn{3}{|c|}{ primary sludge } & \multicolumn{3}{c|}{ Return activated sludge } \\
\cline { 2 - 7 } & Raw & Treated & R\% & Raw & treated & R\% \\
\hline \hline TC & $6.3 \times 10^{5}$ & 0 & 100 & $2.4 \times 10^{7}$ & 5000 & 99.98 \\
\hline FC & $1.8 \times 10^{6}$ & 0 & 100 & $13.3 \times 10^{5}$ & 1000 & 99.92 \\
\hline
\end{tabular}

The obtained results showed high removal efficiency of total coliform and fecal coliform with $99.9 \%$ and $100 \%$, respectively which has remarkable effectand it is due to the strong effect of the high $\mathrm{pH}$ value. Results matched with El-Awady 1998 a, b; El-Awady and Ali 2012 who carried out bacteriological examination on composite samples of primary and RAS for TC and FC with removal efficiencies $100 \%$. 


\section{Physico-chemical and microbiological analyses for the dried raw primary}

\section{and RAS and dried treated sludge with CKD}

The precipitated sludge at the end of each test procedures has been collected and dried at $105^{\circ} \mathrm{C}$. Physico-chemical analyses were shown in Figure (3)

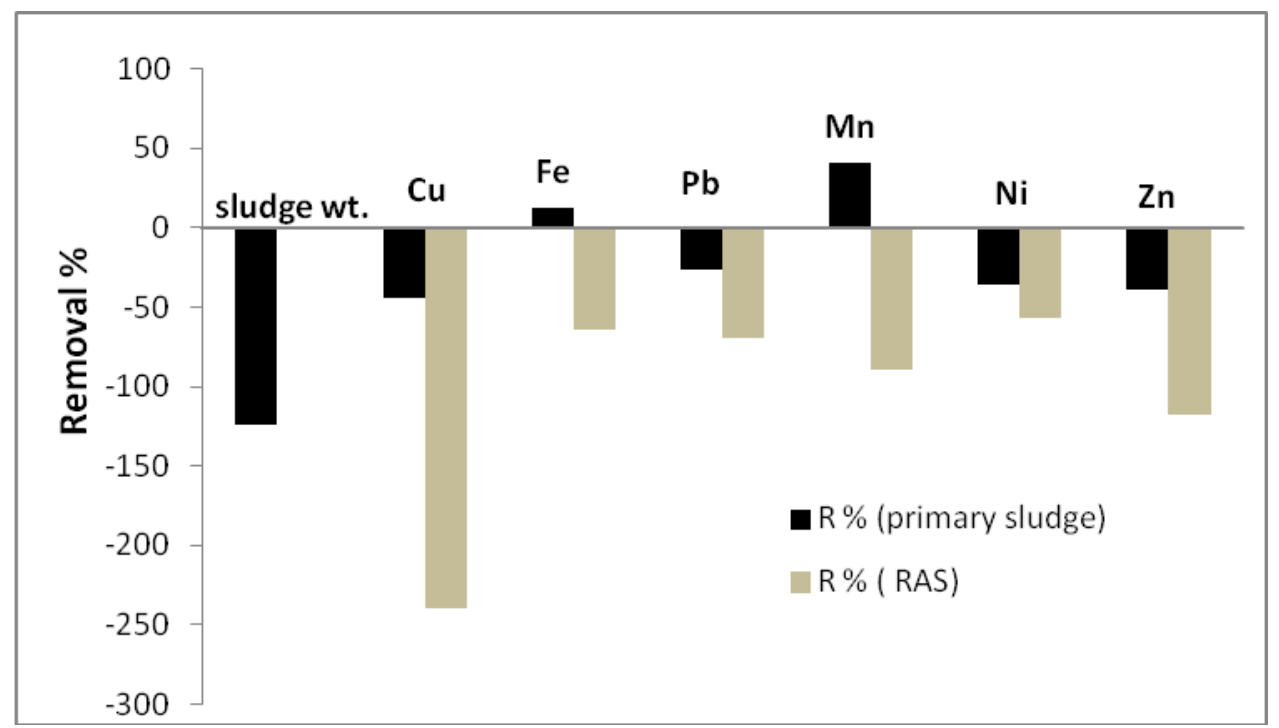

Figure (3): Efficiency of removal for dried raw and treated sludge

Sludge weight of primary sludge increases to $124 \%$ after treatment which matched with Salah and Sabah (2012) who observed that sewage sludge treatment by addition of CKD resulted in an increase in solid content of the sludge. Also the results matched with Allison et al (2010) who use CKDgenerated slurry for the treatment of mine wastewater, resulted in efficient precipitation of metals in the coagulation stage. Specifically, over $99 \%$ of soluble iron and zinc in the raw mine wastewater were transformed into insoluble compounds (precipitates). 
J. Environ. Sci.

Institute of Environmental Studies and Research - Ain Shams University

The microbiological analyses for dried sludge and the treated one were shown in table (4)

Table (4): Efficiency of removal for total coliform and fecal coliform

\begin{tabular}{|c||c|c|}
\hline Parameter & R\% (primary sludge) & R\% (RAS) \\
\hline \hline TC & 99.9 & 99.7 \\
\hline FC & 99.9 & 99.2 \\
\hline
\end{tabular}

The results show high removal efficiency of FC and TC up to $99 \%$ after applying the optimum conditions and this is due to the high $\mathrm{pH}$. Results matched with El-Awady and Ali (2012) who found that CKD addition to sewage sludge destructed all types of viruses, parasites, pathogenic bacteria, and all types of other harmful microorganisms.

\section{SUMMARY}

\section{From the previous results, the following can be concluded:}

- The obtained results of the treatment of primary sludge and return activated sludge using CKD as a coagulant at their optimum operating conditions, with the high $\mathrm{pH}$ value which control the release of heavy metals via changing the cationic ions into a hydroxide forms.

- The silicate as well as calcium compounds contained in CKD behaved as an adsorbent material. Moreover, the high $\mathrm{pH}$ value destructed all types of pathogenic viruses. As a result of these effects, the CKD behaved as an adsorbent material, in addition to help suspended materials to be compacted and reduce the fluffy volume of sludge to the minimum. The solid compaction helps the water part to be separated from sludge matrix. 
The produced water can easily recycled and the solids be dried in few days.

- Addition of $8 \mathrm{~g} / \mathrm{l} \mathrm{CKD}$ to the primary sludge and $7 \mathrm{~g} / \mathrm{l}$ to the return activated sludge achieved an excellent removal of different organic and inorganic analytes.

- The chemical treatment of sewage sludge using CKD as coagulant and flocculants is preferred because of the high removal of solids, BOD5, COD, Nitrogen, sulphide and phosphates.

\section{REFERENCES}

Allison, L.M. ; Heather, F.A. and Margaret, E. (2010): Mine Water treatment with cement Kiln Dust (CKD), International mine water association symposium 2010, "Mine Water and Innovative Thinking", Sydney, Nova Scotia, Canada.

Allison, L.M. and Margaret, E. (2012): Bench-scale study of active mine water treatment using cement kiln dust (CKD) as a neutralization agent, Water Research 46: 327- 334.

Al-Meshragi, M., Ibrahim, H.G. and Abo-abboud, M.M. (2008): Equilibrium and kinetics of chromium adsorption on cement kiln dust. Proceeding of the world congress on engineering and computer science, San Francisco, USA, WCECS pp. 54-62.

Brian, K.R.; John, H. P.; Tammo, S.S. and Barry, N.L (1997): Effect of Processing Mode on Trace Elements in Dewatered Sludge Products Journal of Environmental Quality 26,782-788.

Cleverson V. A., Marcos V. S. and fernandes (2007): Sludge treatment and disposal (Assessment of sludge treatment and sludge disposal) Volume 6, chapter 7, published by IWA, London, UK.

El-Awady, M.H., and Ali, S.A. (2012): Nonconventional treatment of sewage sludge using cement kiln dust for reuse and catalytic conversion of hydrocarbons, The Environmentalist, 32(4), 464-475. 
El-Awady, M.H., and Sami, T.M. (1997): Removal of heavy metals by cement kiln dust. Bulletin of environmental contamination and toxicology, 59(4), 603-610.

El-Awady, M.H. (1998a): a reliable approach for sewage treatment in developing countries, Egyptian Society of Engineers, 37 (1), 4245.

El-Awady, M.H., (1998b): Chemical treatment of sewage sludge for reuse, Sci Bull. Fac. Eng. Ain Shams Univ., Vol. 33, No.1, 133-140

El-Mahllawy, M.S. (2013), an investigation on the effect of cement kiln dust and Glauconite on the properties of acid resisting brick, Int. J. Sci. Tech, 2, 30.

Eugene W. R., Rodger B. B. , Andrew D. E. and Lenore S. C. (2012): Standard Methods for the examination of Water and Wastewater, $22^{\text {nd }}$ Edition, American Public Health Association, American Water Works Association, Water Environment Federation, USA.

George, T., Franklin, L. B. and David, H. S. (2003), Wastewater Engineering (Treatment and Reuse), Chapter14, $4^{\text {th }}$ Edition, 1449-1631.

Mackie, A., Boilard, S., Walsh',M.E. and Lake, C.B. (2010), Physicochemical characterization of cement kiln dust for potential reuse in acidic wastewater treatment, Journal of Hazardous Materials, 173(1-3), 283-291.

Mahmoud, E.K., (2010): Cement kiln dust and coal filters treatment of textile in industrial effluents. Desalination 255, 175-178.

Mahmoud, E.K., (2014), Application of cement kiln dust for chemically enhanced primary treatment of municipal wastewater. Desalin. Water Treat. 52, 4698-4704.

Margarita, G.; Dalia, V.; Vidas, P.; Remigijus, J. and Albinas, P. (2005): Interaction of heavy metal ions with cement kiln Dust, EKOLOGIJA. Nr. 1, 31-36.

Mostafa, A. H. (2012): Effect of cement kiln dust addition on activated sludge process without primary settling for reuse applications. HBRC Journal, 8(1), 14-25. 
Rahman, M. K., Rehman, S., and Al-Amoudi, O. S. B. (2011): Literature review on cement kiln dust usage in soil and waste stabilization and experimental investigation. International Journal of Research and Reviews in Applied Sciences, 7(1), 77-87.

Salah, F. A. and Sabah, U.S. (2012): CKD Use as a sludge stabilization, dewatering and disinfection agent in Iraq, International Journal of Scientific \& Engineering Research, 3(11),1-24.

Salem, W.M., Sayed W.F., Halawy, S.A. and Elamary, R.B. (2015): Physicochemical and microbiological characterization of cement kiln dust for potential reuse in wastewater treatment, Ecotoxicology and environmental safety, 119, 155-161.

Selvi, K., Pattabhi, S. and Kadirvelu, K. (2001), Removal of Cr (VI) from aqueous solution by adsorption onto activated carbon. Bioresour. Technol. 80, 87-89.

Taha, A.; Dakroury, A. M.; Sayed, G. E. and El-Salam,S. A. (2007): Assessment removal of heavy metals ions from wastewater by cement kiln dust (CKD), $11^{\text {th }}$ International Water Technology Conference, IWTC11, Sharm El-Sheikh, Egypt, 879-893.

Technical Report (2013): Holding Company for Water and Wastewater; HCWW-report.

Usama, A. and Rafik, K. (2013): Optimization of Cement Kiln Dust Usage for Removing Different Metals from Synthetic Raw Water, Journal of American Science 9(12):784-793.

Yurtsever, D. (2005): Use of treatment plant sludges as biosolid. M. Sc. Thesis, Faculty of Engineering, Department of Environmental Engineering, Izmir, Turkey.

Zaki, N. G., Khattab, I. A., \& El-Monem, N. A. (2007): Removal of some heavy metals by CKD leachate. Journal of hazardous materials, 147(1), 21-27. 


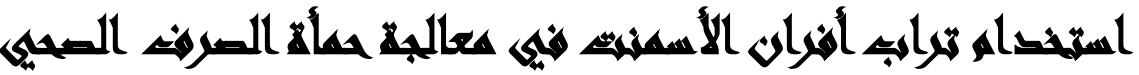



\section{[1]}

محمد حمدى العوضى(')- صلاح عبد الغتى أبو العينين(r)- شادى محمد أنور (r)


والصرف الصحى.

\section{المستخلي}



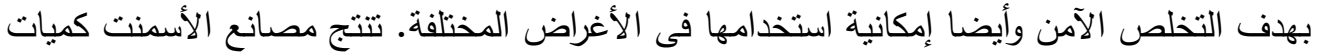



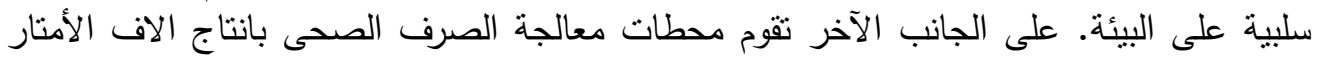



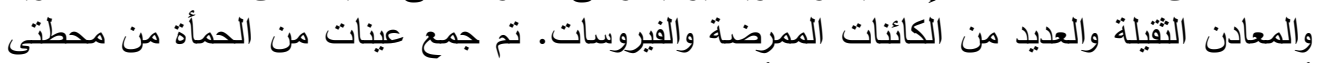

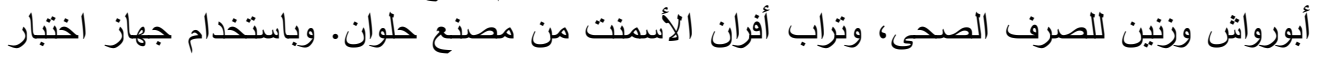

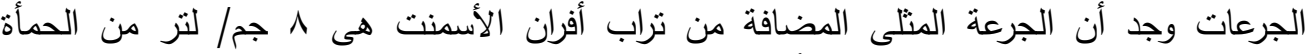

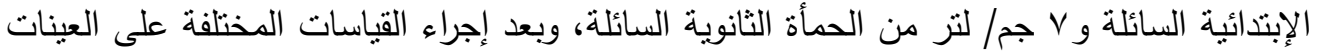

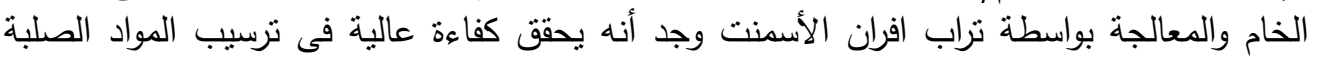

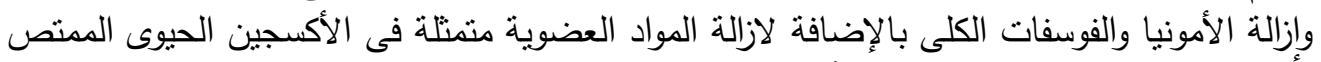

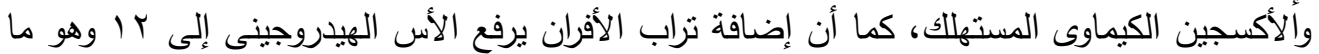

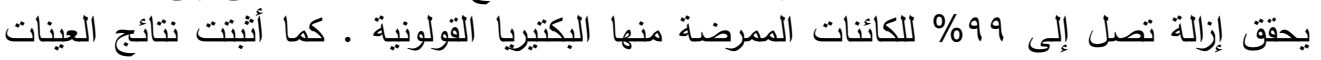

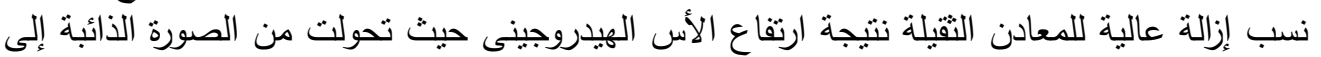
الصورة غير الذائبة وترسبت فى صورة هيدروكسيدات. 